Article

\title{
A New Graphitic Nitride and Reduced Graphene Oxide-Based Sulfur Cathode for High-Capacity Lithium-Sulfur Cells
}

\author{
Artur M. Suzanowicz ${ }^{1}$, Youngjin Lee ${ }^{1}$, Hao Lin ${ }^{2}$, Otavio J. J. Marques ${ }^{2}$, Carlo U. Segre ${ }^{2}$ (D) \\ and Braja K. Mandal ${ }^{1, *(D)}$ \\ 1 Department of Chemistry, Illinois Institute of Technology, Chicago, IL 60616, USA; \\ asuzanow@hawk.iit.edu (A.M.S.); ylee101@hawk.iit.edu (Y.L.) \\ 2 Department of Physics \& CSRRI, Illinois Institute of Technology, Chicago, IL 60616, USA; \\ hlin46@hawk.iit.edu (H.L.); ojovinomarques@hawk.iit.edu (O.J.J.M.); segre@iit.edu (C.U.S.) \\ * Correspondence: mandal@iit.edu
}

Citation: Suzanowicz, A.M.; Lee, Y.; Lin, H.; Marques, O.J.J.; Segre, C.U.; Mandal, B.K. A New Graphitic Nitride and Reduced Graphene Oxide-Based Sulfur Cathode for High-Capacity Lithium-Sulfur Cells. Energies 2022, 15, 702. https:// doi.org/10.3390/en15030702

Academic Editor: Hena Das

Received: 22 November 2021

Accepted: 5 January 2022

Published: 19 January 2022

Publisher's Note: MDPI stays neutral with regard to jurisdictional claims in published maps and institutional affiliations.

Copyright: (C) 2022 by the authors. Licensee MDPI, Basel, Switzerland. This article is an open access article distributed under the terms and conditions of the Creative Commons Attribution (CC BY) license (https:// creativecommons.org/licenses/by/ $4.0 /)$.

\begin{abstract}
Lithium-sulfur (Li-S) batteries can provide at least three times higher energy density than lithium-ion (Li-Ion) batteries. However, Li-S batteries suffer from a phenomenon called the polysulfide shuttle (PSS) that prevents the commercialization of these batteries. The PSS has several undesirable effects, such as depletion of active materials from the cathode, deleterious reactions between the lithium anode and electrolyte soluble lithium polysulfides, resulting in unfavorable coulombic efficiency, and poor cycle life of the battery. In this study, a new sulfur cathode composed of graphitic nitride as the polysulfide absorbing material and reduced graphene oxide as the conductive carbon host has been synthesized to rectify the problems associated with the PSS effect. This composite cathode design effectively retains lithium polysulfide intermediates within the cathode structure. The S@RGO/GN cathode displayed excellent capacity retention compared to similar RGO-based sulfur cathodes published by other groups by delivering an initial specific capacity of $1415 \mathrm{~mA} \mathrm{~h} \mathrm{~g}^{-1}$ at $0.2 \mathrm{C}$. In addition, the long-term cycling stability was outstanding (capacity decay at the rate of only $0.2 \%$ per cycle after 150 cycles).
\end{abstract}

Keywords: Li-S cells; reduced graphene oxide; graphitic nitride; polysulfide shuttle; polysulfide absorbing material; sulfur cathode composite

\section{Introduction}

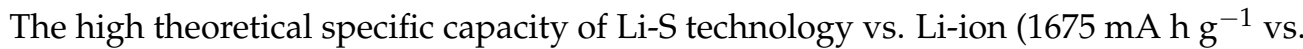
$350 \mathrm{~mA} \mathrm{~h}^{-1}$ ) and superior energy density ( $2600 \mathrm{~W} \mathrm{~h} \mathrm{~kg}^{-1} \mathrm{vs}$. $300 \mathrm{~W} \mathrm{~h} \mathrm{~kg}^{-1}$ ) make Li-S technology more desirable over Li-ion technology [1,2]. Furthermore, sulfur is a plentiful resource; it is inexpensive and environmentally friendly. Thus, the commercialization of Li$S$ technology would significantly reduce the cost of electric vehicles and portable electronic devices [1,2]. Nevertheless, to make this technology commercially viable, the cathode material requires optimization in several areas, such as conductivity, containment of soluble lithium polysulfide intermediates (viz., $\mathrm{Li}_{2} \mathrm{~S}_{8}, \mathrm{Li}_{2} \mathrm{~S}_{6}$, and $\mathrm{Li}_{2} \mathrm{~S}_{4}$ ), and accommodation of sizeable volumetric expansion during discharge (reduction). Additionally, sulfur's low conductivity and the discharge products $\mathrm{Li}_{2} \mathrm{~S}_{2}$ and $\mathrm{Li}_{2} \mathrm{~S}$ prevent full utilization of these active materials. In ether-based electrolytes, the soluble intermediates (higher-order lithium polysulfides) diffuse from the cathode and irreversibly "shuttle" to the anode. Furthermore, sulfur undergoes a density change from $2.03 \mathrm{~g} \mathrm{~cm}^{-3}$ to $1.66 \mathrm{~g} \mathrm{~cm}^{-3}$ when it reacts with $\mathrm{Li}^{+}$during discharge resulting in an $\sim 80 \%$ volumetric change. This repeated expansion during discharge and contraction during charge destroys the cathode structure and the organization of active materials, leading to poor Coulombic efficiency and rapid capacity fading [3-5].

In the past two decades, extensive research has been conducted to address the insulating nature of sulfur by incorporating it in porous carbons [6-11] and carbon 
nanotubes [12-15]. Designs with reduced graphene oxide (RGO) and graphene [16-24] have also been explored extensively. While the carbon-based cathode structures provide good electrical conductivity and room for volume expansion, the complete retention of lithium polysulfides (LiPSs) in the cathode structure is difficult because of the lack of poor interactions (carbon is nonpolar while LiPSs are polar). Thus, continuous capacity fading is unavoidable when the cathode structure is made of only carbon $[25,26]$. Several researchers expanded the composition of the host by including polar materials, such as $\mathrm{N}$ and $\mathrm{P}$ doped carbon [27-29]. These materials, along with metal-organic frameworks (MOFs) [30,31], and $\mathrm{TiO}_{2}$ [32-36], have been proven effective in anchoring LiPSs. Other materials, such as graphitic carbon nitride $\left(\mathrm{GN}, g-\mathrm{C}_{3} \mathrm{~N}_{4}\right)$ [37-39] and $\mathrm{MnO}_{2}$ [40-42], also offer LiPSs' containment abilities.

Polymer-based sulfur cathodes have also been under extensive investigation to solve the insulation and shuttle issues [40-42]. For example, when made composite with sulfur, a conducting polymer, such as polypyrrole displayed superior initial discharge capacity (1280 $\left.\mathrm{mAh} \mathrm{g}^{-1}\right)$ and good polysulfide retention properties [43]. Conducting polymers offers several features, viz., enhanced electrical conductivity of the cathode, lowtemperature synthesis, strong bonding with the polysulfide intermediates through the radical, cationic species present in the conducting polymer backbone. Organo-sulfur polymer-based cathodes, first developed by the free-radical copolymerization of sulfur and divinylic monomers [44], have also been extensively studied. These materials displayed a discharge capacity of $823 \mathrm{mAh} \mathrm{g}^{-1}$ after 100 cycles. Subsequently, several other organo-sulfur polymer cathodes involving alkene/alkyne [45,46], thiols [47,48], and nitrilesderived composites $[49,50]$ were developed. Several mechanisms have been suggested to describe the structural evolution of organo-sulfur polymers. It is concluded that the polysulfide moieties bonded to the organic matrix are the main discharge products.

With the aid of density functional theory, Cui and co-workers demonstrated that carbon hosts containing a small proportion of sulfur, nitrogen, or oxygen remarkably improve the bonding between the host and the LiPSs [51]. Thus, a specifically designed conductive carbon host containing a polysulfide absorbing material may provide a sulfur cathode with fast electrode kinetics and superior capacity retention. Since a cathode is typically composed of $70 \mathrm{wt}$. \% sulfur, the common commercially available carbon blacks, such as Super-P and Ketjen black, are not effective as the carbon host since the resulting carbon-sulfur composites are not adequately conductive, which leads to sluggish electrode kinetics.

In this study, our group has designed a new composite sulfur cathode material to trap LiPSs using reduced graphene oxide (RGO) as the conductive carbon host and graphitic nitride (GN) as the polysulfide absorbing material (PAM) [52]. It is noteworthy to mention that RGO is also known to anchor polysulfides via the residual functional groups present on the RGO surface [53]. Furthermore, this cathode design is scalable, unlike most nanocomposite synthetic designs involving RGO that are not feasible to commercialize because they fail either to apply to large-scale production or to succeed in preserving the produced nanomaterials with the desired properties [54]. In most reported nanomaterial synthetic schemes, the use of a vast amount of solvent is of particular concern in both the purification and size control of nanoparticles. Current methods for purification of nanoparticle samples involve washing or extraction to remove impurities. This process typically requires liters of solvent per gram of nanoparticles and yet does not remove all the impurities [55]. Nanomaterials may also negatively impact human health and/or the environment, which are not yet fully understood. Additionally, the quantum mechanics that regulate interactions with other molecules may also make their toxicological behavior difficult to envisage [54].

Our scalable composite cathode design named S@RGO/GN is composed of graphitic nitride as the polysulfide absorbing material and RGO as the conductive carbon host. GN possesses a layered graphite-like structure with a high nitrogen content [56,57], resulting in high polarity and affinity to adsorb LiPSs $[58,59]$. RGO exhibits properties close to 
graphene with an electrical conductivity of $103.3 \mathrm{~S} \mathrm{~cm}^{-1}$ (vs. $\sim 0.5 \mathrm{~S} \mathrm{~cm}^{-1}$ for Super P) [52]. Therefore, we anticipate the cathode structure to display adequate electrical conductivity after sulfur infiltration and thereby ensue as a good polysulfide reservoir by combining the properties of RGO and GN.

\section{Experimental}

\subsection{Materials}

Edge-functionalized graphene-oxide (EFGO) was obtained from Garmor Tech, Orlando, FL. Urea, hydroiodic acid, ethanol, and sulfur were all purchased from Alfa Aesar. All reagents were used as received.

\subsection{Preparation of $R G O / G N$ Composite}

RGO/GN was prepared by freeze-drying, followed by carbonization, $\mathrm{HI}$ acid treatment, and vacuum annealing. In a typical experiment, $10 \mathrm{~g}$ of EFGO was combined with $10 \mathrm{~g}$ of urea and sonicated/vortexed in $30 \mathrm{~mL}$ of water for $2 \mathrm{~h}$. The mixture was then frozen overnight and freeze-dried the next day for $48 \mathrm{~h}$. Following freeze-drying, the sample was carbonized under an Ar atmosphere at $550{ }^{\circ} \mathrm{C}$ for $4 \mathrm{~h}$ with a heating rate of $4.4^{\circ} \mathrm{C} \mathrm{min}{ }^{-1}$. Workup consisted of a wash in water followed by $15 \mathrm{~min}$ of air drying. The product was then mixed with $5 \mathrm{~mL}$ of $\mathrm{HI}$ in a round-bottom flask for $2 \mathrm{~h}$ at $80^{\circ} \mathrm{C}$. The reduced product was filtered and washed with water followed by ethanol and dried at $80^{\circ} \mathrm{C}$ in an oven overnight. The dry product was then vacuum annealed at $200^{\circ} \mathrm{C}$ for $6 \mathrm{~h}$.

\subsection{Preparation of $S @ R G O / G N$ Cathode}

The S@RGO/GN composite was prepared by the popular melt-diffusion technique. Elemental sulfur was mixed by grinding with RGO/GN in a weight ratio of 7:3. The mixture was then transferred into a Teflon-lined autoclave, heated at $155{ }^{\circ} \mathrm{C}$ for $12 \mathrm{~h}$, and naturally cooled to room temperature.

\subsection{Materials Characterization}

The morphology of our cathode materials was imaged with a scanning electron microscope (SEM), Phenom Pro-X. A copper tape was used as the substrate and was covered with a small amount of each sample. Spot analysis at an accelerating voltage of $15 \mathrm{kV}$ in secondary electron mode was used. S@RGO/GN samples were characterized using a Powder-XRD (Bruker D2 Phaser) instrument in Bragg-Brentano geometry utilizing $\mathrm{Ni}$-filtered $\mathrm{Cu} \mathrm{K} \alpha$ radiation. A LynxEye linear position-sensitive detector was used at a range of $10^{\circ}$ to $80^{\circ} 2 \theta$ degrees. The XRD pattern of S@RGO/GN powder was evaluated with the Rietveld refinement method by using the General Structure Analysis System II (GSAS-II) program [60].

\subsection{Electrochemical Measurements}

A viscous slurry was cast as the cathode film, which consisted of $80 \mathrm{wt} . \%$ active material, 10 wt. \% Super P carbon and 10 wt. \% of polyvinylidene fluoride (PVDF) in $\mathrm{N}$-methyl pyrrolidone (NMP). The mixture was vortexed overnight. The cathode composite film was cast on an $\mathrm{Al}$ foil, which served as the current collector. The coated foil was dried overnight at $60{ }^{\circ} \mathrm{C}$. After drying, the cathodes were cut to $9 / 16^{\prime \prime}(1.43 \mathrm{~cm})$ discs. The active material (sulfur) weight in the composite film ranged from 0.95 to $1.5 \mathrm{mg} \mathrm{cm}^{-2}$. CR2032type coin cells were used to evaluate the electrochemical performance along with Li metal as the anode. The separator was a Celgard porous membrane. The electrolyte consisted of $25 \mu \mathrm{L}$ of $1 \mathrm{M}$ lithium bis (trifluoromethanesulfonyl)imide (LiTFSI) in 1,2-dimethoxyethane $(\mathrm{DME})$ and 1,3-dioxolane (DOL) $(v / v=1: 1)$ solution with $2 \mathrm{wt}$. $\% \mathrm{LiNO}_{3}$ as an additive. The cells were assembled in less than $1 \mathrm{ppm} \mathrm{O}_{2}$ by utilizing a glove box under argon gas. Cyclic voltammetry (CV) was performed using a scan rate of $0.0001 \mathrm{~V} / \mathrm{s}$. Electrochemical impedance spectroscopy (EIS) was performed in the range of $100,000 \mathrm{~Hz}$ to $0.01 \mathrm{~Hz}$. 


\section{Results and Discussion}

Figure 1 depicts the schematics of the synthetic strategy for the S@RGO/GN composite cathode material. The methodology involved mixing, freeze-drying, calcination, and reduction using HI to make the porous RGO/GN host (may be referred to as Void@RGO/GN), which was converted to the desired cathode by sulfur infiltration. We used commercially available inexpensive EFGO as the precursor to RGO because of its high solubility in water. This will enable the incorporation of GN sheets between RGO sheets. Urea and melamine are commonly used as precursors for producing GN [61-64]. We have chosen urea due to its high solubility in water compared to melamine. Moreover, urea is believed to promote the exfoliation of graphene oxide (GO) sheets through hydrogen bonding between the polar groups present in the central area of the graphene sheet and urea. Based on our previous study involving GN [65], we tried to limit the loading of GN between 10 and $15 \mathrm{wt}$. \%, a condition to achieve both good conductivity and superior polysulfide absorbing characteristics of the composite cathode. GO is traditionally reduced to RGO either thermally $\left(900^{\circ} \mathrm{C}\right)$ or chemically. We had to choose the chemical method because the thermal method would destroy the GN structure. Hence, EFGO was chemically reduced to RGO using HI, followed by thermal annealing [66-68].
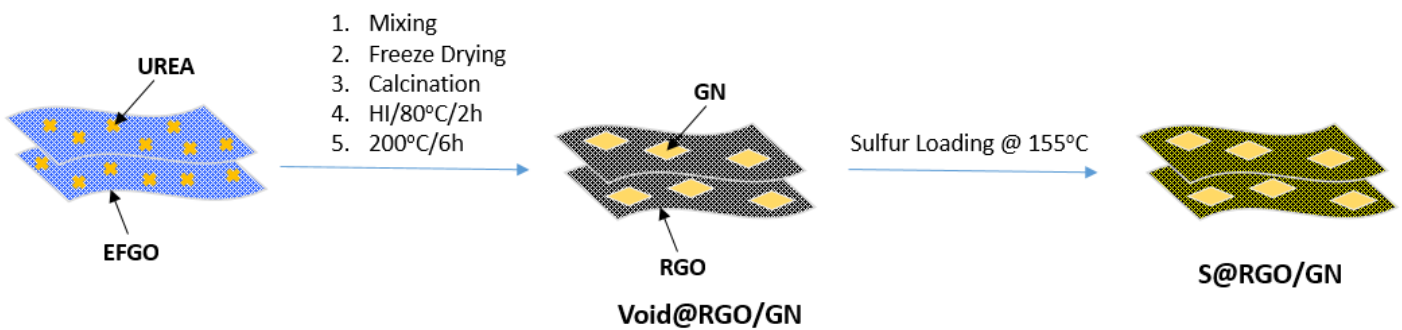

Figure 1. Schematic diagram of the synthesis of S@RGO/GN cathode.

To monitor the morphology of the intermediate products, scanning electron microscope (SEM) images were collected after each step (Figure 2). Sulfur loading into RGO/GN did not alter the morphology or shape of the cathode. Based on the difference of contrast between different spots, one can conclude that sulfur was infiltrated uniformly. Since the infiltration of sulfur was carried out in the molten/vapor phase, sulfur penetrated the structure through the pores, increasing the diameter of the RGO/GN particles and partially covering the surface. The Void@RGO/GN material showed disordered heterogeneous agglomerates of porous architecture (Figure 2a). The S@RGO/GN SEM images gave evidence of sulfur infiltration as the shade of the agglomerates had significantly increased in brightness, indicating the presence of sulfur (Figure 2b).
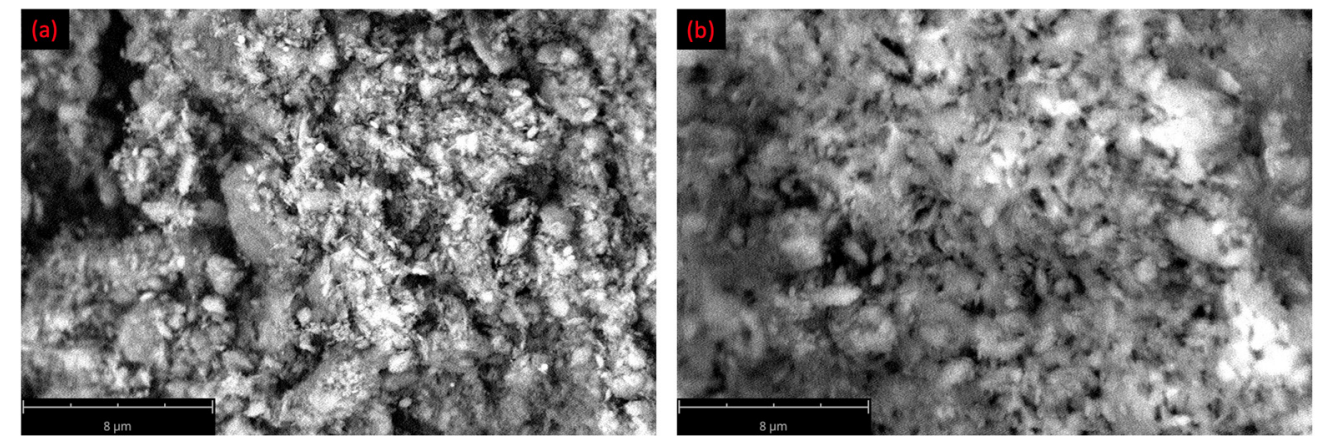

Figure 2. Scanning electron microscope images of (a) Void@RGO/GN and (b) S@RGO/GN.

Table 1 contains the results of energy-dispersive X-ray spectroscopy (EDS) analysis for both Void@RGO/GN and S@RGO/GN samples. Five different spots were selected and scanned for quantitative analysis. The measured data were averaged. The sulfur- 
loaded sample (S@RGO/GN) contained about 2 wt. \% (+/ - 1\%) of elemental nitrogen and 65 wt. $\%(+/-1 \%)$ of sulfur.

Table 1. Energy-dispersive X-ray results of Void@RGO/GN and S@RGO/GN.

\begin{tabular}{ccccc}
\hline \multirow{2}{*}{ Sample } & Atomic Number & Element & $\begin{array}{c}\text { Atomic } \\
\text { Concentration } \\
+/-\mathbf{1} \%\end{array}$ & $\begin{array}{c}\text { Weight } \\
\text { Concentration } \\
+/-\mathbf{1} \%\end{array}$ \\
\hline \multirow{2}{*}{ Void@RGO/GN } & 6 & $\mathrm{C}$ & 57 & 52 \\
\cline { 2 - 5 } & 7 & $\mathrm{~N}$ & 25 & 26 \\
\hline & 8 & $\mathrm{O}$ & 18 & 22 \\
\cline { 2 - 5 } S@RGO/GN & 16 & $\mathrm{~S}$ & 46 & 65 \\
\cline { 2 - 5 } & 8 & $\mathrm{O}$ & 28 & 20 \\
\cline { 2 - 5 } & 6 & $\mathrm{C}$ & 22 & 12 \\
\hline
\end{tabular}

X-ray diffraction (XRD) patterns and parameters collected from S@RGO/GN samples are shown in Figure 3 and Table 2, respectively. The prominent peaks in S@RGO/GN are matched with the sublimed sulfur peaks (ICDD PDF card number 00-008-0247) with orthorhombic crystal structure and Fddd space group. The lattice parameters $[\mathrm{a}=10.4941(6)$ $\mathrm{b}=12.9086(7) \mathrm{c}=24.5432(12)]$ and the refined particle size of 65.7(1) nm were obtained using GSAS-II [60]. The prominent peaks of graphitic nitride were difficult to detect, and this was due to the low percentage of GN present in the sample compared to the dominant sulfur phase. However, the inset in Figure 3 shows that carbon is present when the experimental data is only fitted with sulfur, and it is most apparent in the blue difference trace at the bottom of the plot.

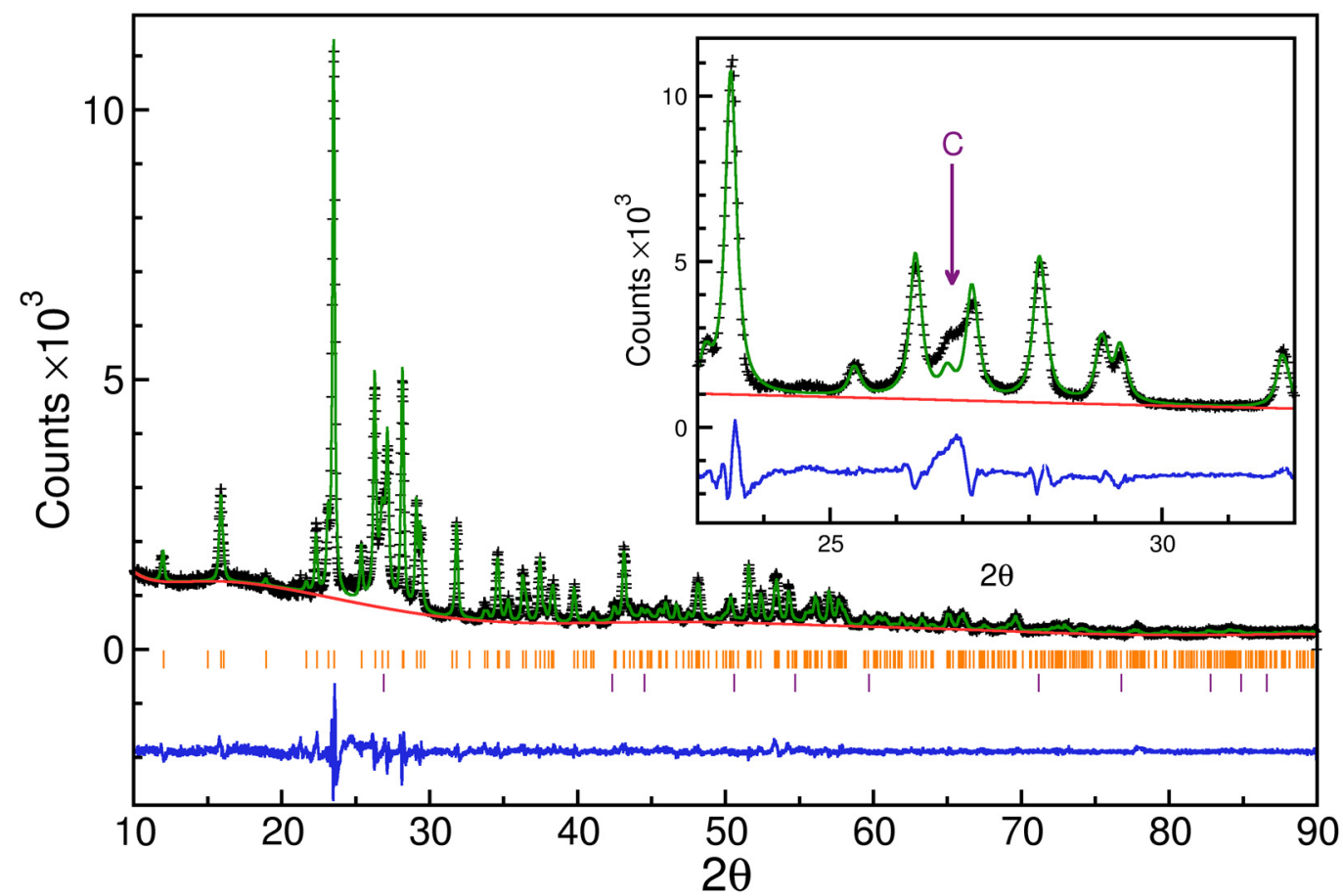

Figure 3. X-ray diffraction pattern for S@RGO/GN showing experimental data (black), Rietveld fit (green), background (red), and difference (blue). Tick marks indicate diffraction peak positions for alpha-sulfur (orange) and graphite (magenta). The inset shows the position of the principal carbon peak when graphite is omitted from the fit. 
Table 2. X-ray diffraction parameters for S@RGO/GN.

\begin{tabular}{ccccc}
\hline Atom & $\mathbf{x}$ & $\mathbf{y}$ & $\mathbf{z}$ & $\mathbf{B}$ \\
\hline S1 & $0.8572(5)$ & $0.9536(3)$ & $-0.0499(2)$ & 0.06 \\
\hline S2 & $0.7852(5)$ & $0.0318(4)$ & $0.0751(2)$ & 0.06 \\
\hline S3 & $0.7090(6)$ & $0.9821(3)$ & $0.0050(2)$ & 0.06 \\
\hline S4 & $0.7848(4)$ & $0.9072(4)$ & $0.1298(2)$ & 0.06 \\
\hline \multicolumn{2}{c}{ Structure } & Space group & Weight fraction \% & R-factor \% \\
\hline \multicolumn{2}{c}{ Alpha-sulfur (8) } & Fddd & 71 & 3.6 \\
\hline \multicolumn{2}{c}{ Graphite } & P63/mm & 29 & 2.4 \\
\hline \multicolumn{2}{c}{ Refinement weighted R-factor } & & 6.3 \\
\hline
\end{tabular}

The electrochemical performance was evaluated by fabricating CR-2032 coin cells. The cells were comprised of S@RGO/GN (cathode)-electrolyte/separator-metallic lithium (anode). Figure 4a shows a cyclic voltammogram curve of the S@RGO/GN cathode. The $\mathrm{CV}$ was scanned in the potential range of $1.5-3.0 \mathrm{~V}$ at a scan rate of $0.1 \mathrm{mV} \mathrm{s}^{-1}$. A typical $\mathrm{CV}$ curve for Li-S cells will show two reduction and oxidation peaks. Reduction takes place when high order and low order polysulfides are formed, i.e., $\left(\operatorname{Li}_{2} \mathrm{~S}_{n}, 4 \leq n \leq 8\right)$ and $\left(\mathrm{Li}_{2} \mathrm{~S}_{2} / \mathrm{Li}_{2} \mathrm{~S}\right)$, respectively. Oxidation occurs when $\mathrm{Li}_{2} \mathrm{~S}_{2} / \mathrm{Li}_{2} \mathrm{~S}$ is converted to high order polysulfides and, ultimately, back to sulfur [69]. In our case, during discharge, only one cathodic peak (bottom) appeared at 1.9-2.3 V. The peak corresponds to the reduction of elemental sulfur to the higher-order soluble $\mathrm{LiPSs}\left(\mathrm{Li}_{2} \mathrm{~S}_{\mathrm{n}}, 4 \leq n \leq 8\right)$ and to the insoluble lower-order LiPSs (viz. $\mathrm{Li}_{2} \mathrm{~S}_{2}$ and $\mathrm{Li}_{2} \mathrm{~S}$ ). Similarly, only one anodic peak (top) at $2.3-2.6 \mathrm{~V}$ was observed during the charging process. This peak represents the formation of both higher-order polysulfides (viz. $\mathrm{Li}_{2} \mathrm{~S}_{8}$ ) and then elemental sulfur through the oxidation of lower-order LiPSs $[65,70,71]$. Electrochemical impedance spectroscopy was utilized to assess the diffusion rate of $\mathrm{Li}^{+}$and the electronic conductivity of the cathode material (Figure $4 \mathrm{~b}$ ). The EIS plot was fitted with an equivalent circuit (Figure $4 b$ ), where CPE is the constant phase element, $R_{0}$ represents the electrolyte ohmic resistance displayed by the semicircle in the high-frequency region, $\mathrm{R}_{\mathrm{ct}}$ corresponds to the charge transfer resistance as well as the diameter of the semicircle, and $W_{0}$ denotes the Warburg impedance. It is displayed by the inclined line (dotted) in the low-frequency region [69-72].
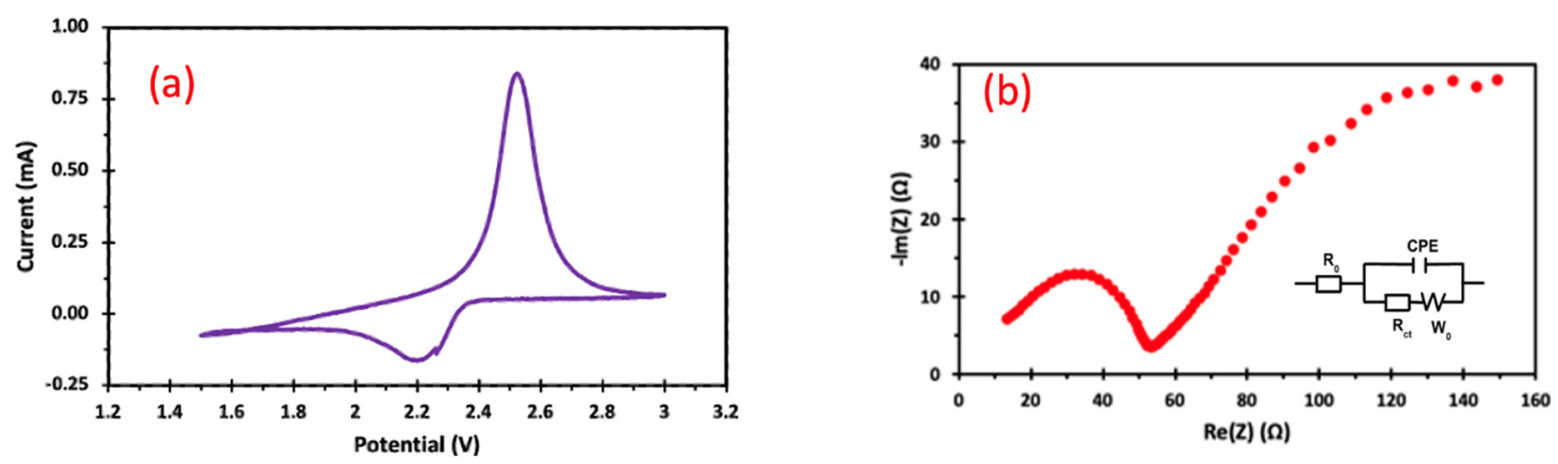

Figure 4. (a) Cyclic voltammogram curve of the S@RGO/GN composite electrode between 1.5 and $3 \mathrm{~V}$ at a scan rate of $0.1 \mathrm{mV} \mathrm{s}^{-1}$, (b) Electrochemical impedance spectroscopy plot of S@RGO/GN with an equivalent circuit.

Figure 5a displays the coulombic efficiency of the S@RGO/GN cathode at the rate of $0.2 \mathrm{C}$ for 150 cycles, along with the cycling stability. The very high initial discharge capacity of $1415 \mathrm{~mA} \mathrm{~h} \mathrm{~g}^{-1}$ indicates that the cathode preparation consisted of well-dispersed sulfur in the RGO/GN host structure. After 150 cycles, the discharge capacity was decreased to $951 \mathrm{~mA} \mathrm{~h} \mathrm{~g}^{-1}$, correlating to $67.2 \%$ capacity retention. At the same time, however, the 
coulombic efficiency ratio of the discharge capacity after the full charge and the charging capacity of the same cycle was highly favorable and close to a ratio of 1 .
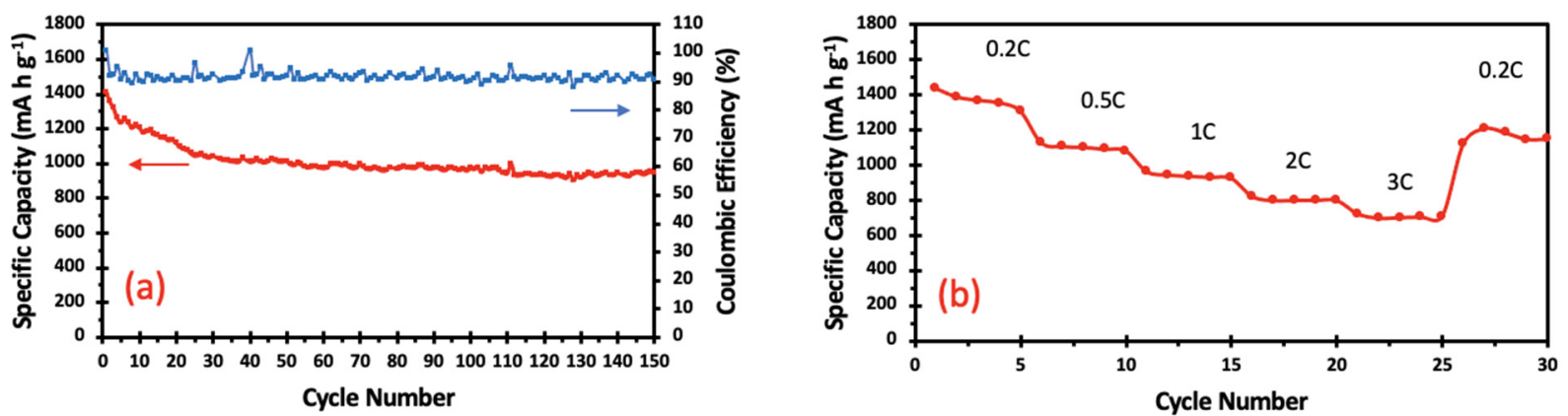

Figure 5. (a) Long-term capacity retention of the cathode at $0.2 \mathrm{C},(\mathbf{b})$ variable rate performance of S@RGO/GN cathode.

After the first cycle, the discharge capacity was reduced to $1360 \mathrm{~mA} \mathrm{~h} \mathrm{~g}^{-1}$, as noticed in the second cycle. The capacity loss continued until the 20th cycle $\left(1121 \mathrm{~mA} \mathrm{~h} \mathrm{~g}^{-1}\right)$, after which the cell became stabilized and the capacity fading rate was significantly smaller. We presume that a sound solid-electrolyte interphase (SEI) did not fully form at the initial cycling stage, giving rise to fast capacity fading. Numerous Li-S battery studies have displayed comparable performance [70,73]. Additionally, agglomeration and sulfur excess may have led to incomplete activation in the redox reaction of several sulfur particles [71]. It is important to note that the capacity retention of our cell between 50 and 150 cycles was very high $(\sim 94 \%)$. Under 50 cycles, there was a loss of active material caused by the polysulfide shuttle due to excess sulfur located on the outer surface of the cathode composite. Still, after 50 cycles, the impact of the polysulfide shuttle became markedly diminished.

The rate performance of the $\mathrm{S} @ \mathrm{RGO} / \mathrm{GN}$ cathode was determined by cycling coin cells through a gradual increase of current densities $(0.2 \mathrm{C}, 0.5 \mathrm{C}, 1 \mathrm{C}, 2 \mathrm{C}$, and $3 \mathrm{C})$ followed by switching back to the initial current density of $0.2 \mathrm{C}\left(1 \mathrm{C}=1675 \mathrm{~mA} \mathrm{~g}^{-1}\right)$. Each cell was tested for 5 cycles at the designated current density to record the corresponding specific discharging capacity after each cycle (Figure $5 b$ ). The S@RGO/GN cathode delivered a very high initial specific capacity of $1437 \mathrm{~mA} \mathrm{~h} \mathrm{~g}^{-1}$ at $0.2 \mathrm{C}$, which is $\sim 84 \%$ of its theoretical capacity. This capacity is nearly the same as the cell in Figure 5a, thus demonstrating cell-to-cell consistency. After the first 5 cycles, the cells became stabilized to a great extent. However, specific capacities gradually decreased with the increase of current density due to slow redox reaction kinetics (probably due to poor $\mathrm{Li}^{+}$diffusion through sulfur and/or lack of a superior electron conduction pathway). The specific capacity of the S@RGO/GN cathode was recorded at $1437,1128,964,823$, and $725 \mathrm{~mA} \mathrm{~h} \mathrm{~g}^{-1}$ at $0.2 \mathrm{C}, 0.5 \mathrm{C}, 1 \mathrm{C}, 2 \mathrm{C}$, and $3 \mathrm{C}$, respectively. When the current density returned to $0.2 \mathrm{C}$, the $\mathrm{S} @ \mathrm{RGO} / \mathrm{GN}$ cathode delivered a specific capacity of $1122 \mathrm{~mA} \mathrm{~h} \mathrm{~g}^{-1}$, which was almost the same value as for the value after the 30th cycle in Figure 5a, showing resistance to degradation from fast cycling. This has exemplified the robustness of the S@RGO/GN cathode after exercising at various rates.

Table 3 represents the electrochemical performance data of S@RGO/GN cathode during long-term cycling (Figure 5a) compared to other nanocomposite materials that utilized GN as the polysulfide absorbing material. Based on the data depicted in Table 3, our cathode material displayed superior capacity and long-term stability compared to several other studies. This enhanced stability is attributed to the excellent electrical conductivity of RGO and the polysulfide absorption properties of GN. 
Table 3. Comparison between the performance of S@RGO/GN and other cathode nanocomposites that utilized $\mathrm{g}-\mathrm{C}_{3} \mathrm{~N}_{4}$ in their structure $[56-59,65]$.

\begin{tabular}{|c|c|c|c|c|c|}
\hline Cathode & Rate & $\begin{array}{c}\text { Initial } \\
\text { Capacity } \\
\left(\mathrm{mA} \mathrm{h} \mathrm{g}^{-1}\right)\end{array}$ & $\begin{array}{c}\text { Reversible } \\
\text { Capacity } \\
\left(\mathbf{m A ~ h ~} \mathbf{g}^{-1}\right)\end{array}$ & $\begin{array}{c}\text { Cycle } \\
\text { Number }\end{array}$ & Reference \\
\hline Sulfur/CN-550 & $\begin{array}{c}0.39 \mathrm{~mA} \\
\mathrm{~cm}^{-2}\end{array}$ & 1262 & 605 & 500 & [56] \\
\hline \multirow[t]{3}{*}{$\mathrm{S} / \mathrm{g}-\mathrm{C}_{3} \mathrm{~N}_{4}$} & $0.2 \mathrm{C}$ & 1200 & 806 & 100 & [57] \\
\hline & $0.5 \mathrm{C}$ & 1092 & 601 & 500 & \\
\hline & $2 \mathrm{C}$ & 875 & 580 & 300 & \\
\hline S/CNG-10 & $100 \mathrm{~mA} \mathrm{~g}^{-1}$ & 1075 & 505 & 600 & [58] \\
\hline hrGO/S-GCM & $0.1 \mathrm{C}$ & 1158 & 575 & 100 & [59] \\
\hline \multirow[t]{2}{*}{$\mathrm{S} @ \mathrm{HCS} @ g-\mathrm{C}_{3} \mathrm{~N}_{4}$} & $0.2 \mathrm{C}$ & 1420 & 885 & 100 & {$[65]$} \\
\hline & $1 \mathrm{C}$ & 953 & 719 & 500 & \\
\hline S@RGO/GN & $0.2 \mathrm{C}$ & 1415 & 951 & 150 & This study \\
\hline
\end{tabular}

\section{Conclusions}

In this study, we have developed a new scalable sulfur cathode structure denoted as S@RGO/GN by infiltrating elemental sulfur into a specifically designed RGO/GN matrix. The cathode structure displayed excellent electrochemical cycling properties $\left(951 \mathrm{~mA} \mathrm{~h} \mathrm{~g}^{-1}\right.$ after 150 cycles at $0.2 \mathrm{C}$ ). This superior cycling performance, especially after and beyond 100 cycles, is believed to occur from GN's effective polysulfide anchoring ability and the high electrical conductivity of RGO, which facilitates fast redox reactions. Further improvement of this RGO/GN structure is underway to enhance PSS retention in the cathode by adding a different polysulfide adsorbing material, such as TiC.

Author Contributions: A.M.S.: conceptualization, methodology, writing—original draft; Y.L.: software, data curation; H.L.: cell fabrication and testing; O.J.J.M.: cell fabrication and testing. C.U.S.: supervision, data interpretation, writing-review \& editing; B.K.M.: conceptualization, methodology, supervision, writing - review \& editing. All authors have read and agreed to the published version of the manuscript.

Funding: This research received no external funding.

Data Availability Statement: Not applicable.

Acknowledgments: We thank the Wanger Institute for Sustainable Energy Research (WISER\# 6-1-19) Foundation for the partial financial support of this research work.

Conflicts of Interest: The authors declare no conflict of interest.

\section{References}

1. Bruce, P.G.; Freunberger, S.A.; Hardwick, L.J.; Tarascon, J.-M. Li-O 2 and Li-S batteries with high energy storage. Nat. Mater. 2011, 11, 19-29. [CrossRef]

2. Manthiram, A.; Fu, Y.; Chung, S.-H.; Zu, C.; Su, Y.-S. Rechargeable lithium-sulfur batteries. Chem. Rev. 2014, 114, 11751-11787. [CrossRef]

3. Yang, Y.; Zheng, G.; Cui, Y. Nanostructured sulfur cathodes. Chem. Soc. Rev. 2013, 42, 3018-3032. [CrossRef] [PubMed]

4. Pang, Q.; Liang, X.; Kwok, C.Y.; Nazar, L.F. Advances in lithium-sulfur batteries based on multifunctional cathodes and elec-trolytes. Nat. Energy 2016, 1, 16132. [CrossRef]

5. Wang, H.; Zhang, W.; Xu, J.; Guo, Z. Advances in Polar Materials for Lithium-Sulfur Batteries. Adv. Funct. Mater. 2018, 28, 1707520. [CrossRef]

6. $\quad$ Liang, C.; Dudney, N.J.; Howe, J.Y. Hierarchically Structured Sulfur/Carbon Nanocomposite Material for High-Energy Lithium Battery. Chem. Mater. 2009, 21, 4724-4730. [CrossRef]

7. Schuster, J.; He, G.; Mandlmeier, B.; Yim, T.; Lee, K.T.; Bein, T.; Nazar, L.F. Spherical Ordered Mesoporous Carbon Nanoparticles with High Porosity for Lithium-Sulfur Batteries. Angew. Chem. Int. Ed. 2012, 51, 3591-3595. [CrossRef] 
8. Chen, S.; Sun, B.; Xie, X.; Mondal, A.K.; Huang, X.; Wang, G. Multi-chambered micro/mesoporous carbon nanocubes as new polysulfides reservoirs for lithium-sulfur batteries with long cycle life. Nano Energy 2015, 16, 268-280. [CrossRef]

9. Li, G.; Sun, J.; Hou, W.; Jiang, S.; Huang, Y.; Geng, J. Three-dimensional porous carbon composites containing high sulfur na-noparticle content for high-performance lithium-sulfur batteries. Nat. Commun. 2016, 7, 10601. [CrossRef]

10. Zheng, Z.; Guo, H.; Pei, F.; Zhang, X.; Chen, X.; Fang, X.; Wang, T.; Zheng, N. High Sulfur Loading in Hierarchical Porous Carbon Rods Constructed by Vertically Oriented Porous Graphene-Like Nanosheets for Li-S Batteries. Adv. Funct. Mater. 2016, 26, 8952-8959. [CrossRef]

11. Wu, R.; Chen, S.; Deng, J.; Huang, X.; Song, Y.; Gan, R.; Wan, X.; Wei, Z. Hierarchically porous nitrogen-doped carbon as cathode for lithium-sulfur batteries. J. Energy Chem. 2018, 27, 1661-1667. [CrossRef]

12. Yuan, L.; Yuan, H.; Qiu, X.; Chen, L.; Zhu, W. Improvement of cycle property of sulfur-coated multi-walled carbon nanotubes composite cathode for lithium/sulfur batteries. J. Power Sources 2009, 189, 1141-1146. [CrossRef]

13. Dörfler, S.; Hagen, M.; Althues, H.; Tübke, J.; Kaskel, S.; Hoffmann, M.J. High capacity vertical aligned carbon nanotube/sulfur composite cathodes for lithium-sulfur batteries. Chem. Commun. 2012, 48, 4097-4099. [CrossRef]

14. Sun, L.; Wang, D.; Luo, Y.; Wang, K.; Kong, W.; Wu, Y.; Zhang, L.; Jiang, K.; Li, Q.; Zhang, Y.; et al. Sulfur Embedded in a Mesoporous Carbon Nanotube Network as a Binder-Free Electrode for High-Performance Lithium-Sulfur Batteries. ACS Nano 2015, 10, 1300-1308. [CrossRef]

15. Yuan, Z.; Peng, H.-J.; Huang, J.-Q.; Liu, X.-Y.; Wang, D.-W.; Cheng, X.-B.; Zhang, Q. Electrodes: Hierarchical free-standing car-bon-nanotube paper electrodes with ultrahigh sulfur-loading for lithium-sulfur batteries. Adv. Funct. Mater. 2014, $24,6244$. [CrossRef]

16. Ji, L.; Rao, M.; Zheng, H.; Zhang, L.; Li, Y.; Duan, W.; Guo, J.; Cairns, E.J.; Zhang, Y. Graphene Oxide as a Sulfur Immobilizer in High Performance Lithium/Sulfur Cells. J. Am. Chem. Soc. 2011, 133, 18522-18525. [CrossRef] [PubMed]

17. Wang, J.-Z.; Lu, L.; Choucair, M.; Stride, J.A.; Xu, X.; Liu, H.-K. Sulfur-graphene composite for rechargeable lithium batteries. J. Power Sources 2011, 196, 7030-7034. [CrossRef]

18. Yuan, S.; Guo, Z.; Wang, L.; Hu, S.; Wang, Y.; Xia, Y. Leaf-Like Graphene-Oxide-Wrapped Sulfur for High-Performance LithiumSulfur Battery. Adv. Sci. 2015, 2, 1500071. [CrossRef]

19. Hu, G.; Xu, C.; Sun, Z.; Wang, S.; Cheng, H.-M.; Li, F.; Ren, W. 3D graphene foam-reduced-graphene-oxide hybrid nested hier-archical networks for high-performance Li-S batteries. Adv. Mater. 2016, 28, 1603-1609. [CrossRef]

20. Chen, L.; Rago, N.L.D.; Bloom, I.D.; Shaw, L.L. New insights into the electrode mechanism of lithium sulfur batteries via air-free post-test analysis. Chem. Commun. 2016, 52, 9913-9916. [CrossRef]

21. Chabu, J.M.; Zeng, K.; Jin, G.; Zhang, M.; Li, Y.; Liu, Y.-N. Simple approach for the preparation of nitrogen and sulfur codoped carbon dots/reduced graphene oxide as host for high-rate lithium sulfur batteries. Mater. Chem. Phys. 2019, 229, $226-231$. [CrossRef]

22. Shi, J.-L.; Tang, C.; Huang, J.-Q.; Zhu, W.; Zhang, Q. Effective exposure of nitrogen heteroatoms in 3D porous graphene framework for oxygen reduction reaction and lithium-sulfur batteries. J. Energy Chem. 2018, 27, 167-175. [CrossRef]

23. Yuan, H.; Peng, H.-J.; Li, B.-Q.; Xie, J.; Kong, L.; Zhao, M.; Chen, X.; Huang, J.-Q.; Zhang, Q. Conductive and Catalytic Triple-Phase Interfaces Enabling Uniform Nucleation in High-Rate Lithium-Sulfur Batteries. Adv. Energy Mater. 2018, 9, 1802768. [CrossRef]

24. Li, Z.; Wu, H.B.; Lou, X.W. Rational designs and engineering of hollow micro-/nanostructures as sulfur hosts for advanced lithium-sulfur batteries. Energy Environ. Sci. 2016, 9, 3061-3070. [CrossRef]

25. Hart, C.J.; Cuisinier, M.; Liang, X.; Kundu, D.; Garsuch, A.; Nazar, L.F. Rational design of sulphur host materials for Li-S batteries: Correlating lithium polysulphide adsorptivity and self-discharge capacity loss. Chem. Commun. 2014, 51, 2308-2311. [CrossRef]

26. Pang, Q.; Tang, J.; Huang, H.; Liang, X.; Hart, C.; Tam, K.C.; Nazar, L.F. A Nitrogen and Sulfur Dual-Doped Carbon Derived from Polyrhodanine@Cellulose for Advanced Lithium-Sulfur Batteries. Adv. Mater. 2015, 27, 6021-6028. [CrossRef]

27. Chen, M.; Jiang, S.; Huang, C.; Wang, X.; Cai, S.; Xiang, K.; Zhang, Y.; Xue, J. Honeycomb-like Nitrogen and Sulfur Dual-Doped Hierarchical Porous Biomass-Derived Carbon for Lithium-Sulfur Batteries. ChemSusChem 2017, 10, 1803-1812. [CrossRef]

28. Chen, L.; Liu, Y.; Ashuri, M.; Liu, C.; Shaw, L.L. Li2S encapsulated by nitrogen-doped carbon for lithium sulfur batteries. J. Mater. Chem. A 2014, 2, 18026-18032. [CrossRef]

29. Zheng, J.; Tian, J.; Wu, D.; Gu, M.; Xu, W.; Wang, C.; Gao, F.; Engelhard, M.H.; Zhang, J.-G.; Liu, J.; et al. Lewis acid-base inter-actions between polysulfides and metal-organic framework in lithium-sulfur batteries. Nano Lett. 2014, 14, $2345-2352$. [CrossRef]

30. Xu, J.; Zhang, W.; Chen, Y.; Fan, H.; Su, D.; Wang, G. MOF-derived porous N-Co $3 \mathrm{O}_{4} @ \mathrm{~N}-\mathrm{C}$ nanododecahedra wrapped with reduced graphene oxide as a high capacity cathode for lithium-sulfur batteries. J. Mater. Chem. A 2018, 6, 2797-2807. [CrossRef]

31. Seh, Z.W.; Li, W.; Cha, J.J.; Zheng, G.; Yang, Y.; McDowell, M.T.; Hsu, P.-C.; Cui, Y. Sulphur-TiO 2 yolk-shell nanoarchitecture with internal void space for long-cycle lithium-sulphur batteries. Nat. Commun. 2013, 4, 1331. [CrossRef]

32. Li, Z.; Guan, B.Y.; Zhang, J.; Lou, X.W.D. A Compact Nanoconfined Sulfur Cathode for High-Performance Lithium-Sulfur Batteries. Joule 2017, 1, 576-587. [CrossRef]

33. Li, Z.; Zhang, J.; Guan, B.; Wang, D.; Liu, L.-M.; Lou, X.W. A sulfur host based on titanium monoxide@carbon hollow spheres for advanced lithium-sulfur batteries. Nat. Commun. 2016, 7, 13065. [CrossRef] 
34. Yao, W.; Chu, C.; Zheng, W.; Zhan, L.; Wang, Y. "Pea-pod-like" nitrogen-doped hollow porous carbon cathode hosts decorated with polar titanium dioxide nanocrystals as efficient polysulfide reservoirs for advanced lithium-sulfur batteries. J. Mater. Chem. A 2018, 6, 18191-18205. [CrossRef]

35. Hwang, J.-Y.; Kim, H.M.; Lee, S.-K.; Lee, J.-H.; Abouimrane, A.; Khaleel, M.A.; Belharouak, I.; Manthiram, A.; Sun, Y.-K. High-energy, high-rate, lithium-sulfur batteries: Synergetic effect of hollow TiO2-webbed carbon nanotubes and a dual functional car-bon-paper interlayer. Adv. Energy Mater. 2016, 6, 1501480. [CrossRef]

36. Pang, Q.; Nazar, L.F. Long-Life and high-areal-capacity Li-S batteries enabled by a light-weight polar host with intrinsic pol-ysulfide adsorption. ACS Nano 2016, 10, 4111-4118. [CrossRef]

37. Liu, J.; Li, W.; Duan, L.; Li, X.; Ji, L.; Geng, Z.; Huang, K.; Lu, L.; Zhou, L.; Liu, Z.; et al. A Graphene-like Oxygenated Carbon Nitride Material for Improved Cycle-Life Lithium/Sulfur Batteries. Nano Lett. 2015, 15, 5137-5142. [CrossRef] [PubMed]

38. Pang, Q.; Liang, X.; Kwok, C.Y.; Kulisch, J.; Nazar, L.F. A Comprehensive Approach toward Stable Lithium-Sulfur Batteries with High Volumetric Energy Density. Adv. Energy Mater. 2016, 7, 1601630. [CrossRef]

39. Liang, X.; Hart, C.J.; Pang, Q.; Garsuch, A.; Weiss, T.; Nazar, L.F. A highly efficient polysulfide mediator for lithium-sulfur batteries. Nat. Commun. 2015, 6, 5682. [CrossRef]

40. Liang, X.; Nazar, L.F. In situ reactive assembly of scalable core-shell sulfur- $\mathrm{MnO}_{2}$ composite cathodes. ACS Nano 2016, 10, 4192-4198. [CrossRef] [PubMed]

41. Ni, L.; Zhao, G.; Yang, G.; Niu, G.; Chen, M.; Diao, G. Dual-core-shell-structured S@C@MnO 2 nanocomposite for highly stable lithium-sulfur batteries. ACS Appl. Mater. Interfaces 2017, 9, 34793-34803. [CrossRef]

42. Wang, J.; Chen, J.; Konstantinov, K.; Zhao, L.; Ng, S.; Wang, G.; Guo, Z.; Liu, H.K. Sulphur-polypyrrole composite positive electrode materials for rechargeable lithium batteries. Electrochim. Acta 2006, 51, 4634-4638. [CrossRef]

43. Li, X.; Yuan, L.; Liu, D.; Li, Z.; Chen, J.; Yuan, K.; Xiang, J.; Huang, Y. High sulfur-containing organosulfur polymer composite cathode embedded by monoclinic $S$ for lithium sulfur bat-teries. Energy Storage Mater. 2020, 26, 570-576. [CrossRef]

44. Wang, C.; Yi, Y.; Li, H.; Wu, P.; Li, M.; Jiang, W.; Chen, Z.; Li, H.; Zhu, W.; Dai, S. Rapid gas-assisted exfoliation promises $\mathrm{V}_{2} \mathrm{O}_{5}$ nanosheets for high performance lithium-sulfur batteries. Nano Energy 2019, 67, 104253. [CrossRef]

45. Sun, Z.; Xiao, M.; Wang, S.; Han, D.; Song, S.; Chen, G.; Meng, Y. Sulfur-rich polymeric materials with semi-interpenetrating network structure as a novel lithium-sulfur cathode. J. Mater. Chem. A 2014, 2, 9280-9286. [CrossRef]

46. Kim, H.; Lee, J.; Ahn, H.; Kim, O.; Park, M.J. Synthesis of three-dimensionally interconnected sulfur-rich polymers for cathode materials of high-rate lithium-sulfur batteries. Nat. Commun. 2015, 6, 7278. [CrossRef]

47. Je, S.H.; Hwang, T.H.; Talapaneni, S.N.; Buyukcakir, O.; Kim, H.J.; Yu, J.-S.; Woo, S.-G.; Jang, M.C.; Son, B.K.; Coskun, A.; et al. Rational Sulfur Cathode Design for Lithium-Sulfur Batteries: Sulfur-Embedded Benzoxazine Polymers. ACS Energy Lett. 2016, 1, 566-572. [CrossRef]

48. Talapaneni, S.N.; Hwang, T.H.; Je, S.H.; Buyukcakir, O.; Choi, J.W.; Coskun, A. Elemental-Sulfur-Mediated Facile Synthesis of a Covalent Triazine Framework for High-Performance Lithium-Sulfur Batteries. Angew. Chem. Int. Ed. 2016, 55, 3106-3111. [CrossRef]

49. Je, S.H.; Kim, H.J.; Kim, J.; Choi, J.W.; Coskun, A. Perfluoroaryl-Elemental Sulfur SNAr Chemistry in Covalent Triazine Frameworks with High Sulfur Contents for Lithium-Sulfur Batteries. Adv. Funct. Mater. 2017, 27, 1703947. [CrossRef]

50. Seh, Z.W.; Zhang, Q.; Li, W.; Zheng, G.; Yao, H.; Cui, Y. Stable cycling of lithium sulfide cathodes through strong affinity with a bifunctional binder. Chem. Sci. 2013, 4, 3673-3677. [CrossRef]

51. Mohan, V.B.; Brown, R.; Jayaraman, K.; Bhattacharyya, D. Characterization of reduced graphene oxide: Effects of reduction variables on electrical conductivity. Mater. Sci. Eng. B Solid-State Mater. Adv. Technol. 2015, 193, 49-60. [CrossRef]

52. Chen, H.; Wang, C.; Dong, W.; Lu, W.; Du, Z.; Chen, L. Monodispersed Sulfur Nanoparticles for Lithium-Sulfur Batteries with Theoretical Performance. Nano Lett. 2014, 15, 798-802. [CrossRef] [PubMed]

53. Charitidis, C.A.; Georgiou, P.; Koklioti, M.A.; Trompeta, A.-F.; Markakis, V. Manufacturing nanomaterials: From research to industry. Manuf. Rev. 2014, 1, 11. [CrossRef]

54. Dahl, J.A.; Maddux, B.; Hutchison, J.E. Toward Greener Nanosynthesis. Chem. Rev. 2007, 107, 2228-2269. [CrossRef]

55. Yao, S.; Xue, S.; Peng, S.; Jing, M.; Qian, X.; Shen, X.; Li, T.; Wang, Y. Synthesis of graphitic carbon nitride at different ther-malpyrolysis temperature of urea and its application in lithium-sulfur batteries. J. Mater. Sci. Mater. Electron. 2018, 29, 17921-17930. [CrossRef]

56. Jia, Z.; Zhang, H.; Yu, Y.; Chen, Y.; Yan, J.; Li, X.; Zhang, H. Trithiocyanuric acid-derived g- $\mathrm{C}_{3} \mathrm{~N}_{4}$ for anchoring the polysulfide in Li-S batteries application. J. Energy Chem. 2020, 43, 71-77. [CrossRef]

57. Wang, M.; Liang, Q.; Han, J.; Tao, Y.; Liu, D.; Zhang, C.; Lv, W.; Yang, Q.-H. Catalyzing polysulfide conversion by g-C $\mathrm{C}_{3} \mathrm{~N}_{4}$ in a graphene network for long-life lithium-sulfur batteries. Nano Res. 2018, 11, 3480-3489. [CrossRef]

58. Li, C.; Gao, K.; Zhang, Z. Graphitic carbon nitride as polysulfide anchor and barrier for improved lithium-sulfur batteries. Nanotechnology 2018, 29, 465401. [CrossRef]

59. Toby, B.; von Dreele, R. GSAS-II: The genesis of a modern open-source all-purpose crystallography software package. J. Appl. Crystallogr. 2013, 46, 544-549. [CrossRef]

60. Liu, J.; Zhang, T.; Wang, Z.; Dawson, G.; Chen, W. Simple pyrolysis of urea into graphitic carbon nitride with recyclable adsorption and photocatalytic activity. J. Mater. Chem. 2011, 21, 14398-14401. [CrossRef] 
61. Zhang, Y.; Liu, J.; Wu, G.; Chen, W. Porous graphitic carbon nitride synthesized via direct polymerization of urea for efficient sunlight-driven photocatalytic hydrogen production. Nanoscale 2012, 4, 5300-5303. [CrossRef] [PubMed]

62. Shcherban, N.D.; Mäki-Arvela, P.; Aho, A.; Sergiienko, S.A.; Yaremov, P.S.; Eränen, K.; Murzin, D.Y. Melamine-derived graphitic carbon nitride as a new effective metal-free catalyst for Knoevenagel condensation of benzaldehyde with ethylcyanoacetate. Catal. Sci. Technol. 2018, 8, 2928-2937. [CrossRef]

63. Li, X.; Zhang, J.; Shen, L.; Ma, Y.; Lei, W.; Cui, Q.; Zou, G. Preparation and characterization of graphitic carbon nitride through pyrolysis of melamine. Appl. Phys. A 2008, 94, 387-392. [CrossRef]

64. Dunya, H.; Yue, Z.; Ashuri, M.; Mei, X.; Lin, Y.; Kucuk, K.; Aryal, S.; Segre, C.U.; Mandal, B.K. A new graphitic carbon nitride-coated dual Core-Shell sulfur cathode for highly stable lithium-sulfur cells. Mater. Chem. Phys. 2020, $246,122842$. [CrossRef]

65. Ahmed, N.S.; Azizi, O.; El-Boher, A.; Gahl, J.; Bok, S. Facile Synthesis and Characterization of Reduced Graphene Oxide Produced with Green and Conventional Reductants. ECS J. Solid State Sci. Technol. 2018, 7, M173-M179. [CrossRef]

66. Moon, I.K.; Lee, J.; Ruoff, R.S.; Lee, H. Reduced graphene oxide by chemical graphitization. Nat. Commun. 2010, 1, 73. [CrossRef]

67. Shruthi, G.; Baishali, G.; Radhakrishna, V.; Verma, P. Reducing graphene oxide using hydroiodic acid fumes and low temperature annealing for enhanced electrical conductivity. Graphene Technol. 2020, 5, 19-25. [CrossRef]

68. Yin, F.; Ren, J.; Zhang, Y.; Tan, T.; Chen, Z. A PPy/ZnO functional interlayer to enhance electrochemical performance of lithium/sulfur batteries. Nanoscale Res. Lett. 2018, 13, 307. [CrossRef] [PubMed]

69. Wang, X.; Li, G.; Li, J.; Zhang, Y.; Wook, A.; Yu, A.; Chen, Z. Structural and chemical synergistic encapsulation of polysulfides enables ultralong-life lithium-sulfur batteries. Energy Environ. Sci. 2016, 9, 2533-2538. [CrossRef]

70. Medenbach, L.; Escher, I.; Köwitsch, N.; Armbrüster, M.; Zedler, L.; Dietzek, B.; Adelhelm, P. Sulfur Spillover on Carbon Materials and Possible Impacts on Metal-Sulfur Batteries. Angew. Chem. Int. Ed. 2018, 57, 13666-13670. [CrossRef] [PubMed]

71. Li, Q.; Liu, J.; Bai, A.; Li, P.; Li, J.; Zhang, X.; Yu, M.; Wang, J.; Sun, H. Preparation of a Nitrogen-Doped Reduced Graphene Oxide-Modified Graphite Felt Electrode for $\mathrm{VO}^{2+} / \mathrm{VO}_{2}{ }^{+}$Re-action by Freeze-Drying and Pyrolysis Method. J. Chem. 2019, 2019, 8958946. [CrossRef]

72. Chen, L.; Liu, Y.; Zhang, F.; Liu, C.; Shaw, L.L. PVP-assisted synthesis of uniform carbon-coated Li 2 S/C.B. for high-performance lithium-sulfur batteries. ACS Appl. Mater. Interfaces 2015, 7, 25748-25756. [CrossRef] [PubMed]

73. Wang, S.; Yang, Z.; Zhang, H.; Tan, H.; Yu, J.; Wu, J. Mesoporous $\beta-\mathrm{MnO}_{2}$ /sulfur composite as cathode material for Li-S batteries. Electrochim. Acta 2013, 106, 307-311. [CrossRef] 